\title{
COMMUNICATION
}

\section{A thermally derived and optimized structure from ZIF-8 with giant enhancement in $\mathrm{CO}_{2}$ uptake}

\author{
Srinivas Gadipelli, ${ }^{a,{ }^{*}}$ Will Travis, ${ }^{a}$ Wei Zhou ${ }^{b, c}$ and Zhengxiao Guo ${ }^{a,{ }^{*}}$
}

Received ooth January 2012,

Accepted ooth January 2012

DOI: $10.1039 / \times 0 x x 00000 x$

www.rsc.org/

We report a new, simple and versatile method to obtain highly active MOF structures by carefully controlled postsynthesis thermal annealing. The active ZIF-8 structure shows highly enhanced $\mathrm{CO}_{2} / \mathrm{N}_{2}$ selectivity and stable cyclic $\mathrm{CO}_{2}$ uptake of $\geq 1.5 \mathrm{mmol} \mathrm{g}^{-1}$ at 1 bar and $25{ }^{\circ} \mathrm{C}$ with a heat of adsorption of $\geq 30 \mathrm{~kJ} \mathrm{~mol}^{-1}$, which is over $100 \%$ greater than the $\approx 0.7 \mathrm{mmol} \mathrm{g}^{-1}$ and $\approx 17 \mathrm{~kJ} \mathrm{~mol}^{-1}$, respectively in the ZIF-8.

Adsorption and separation of gaseous molecules by porous solids is a critical issue in catalysis, sensing, energy storage, $\mathrm{CO}_{2}$ capture and pollutant removal. ${ }^{1}$ In particular, nanoporous solids such as zeolites, carbons and metal-organic frameworks (MOFs) are extensively investigated for clean energy $\left(\mathrm{H}_{2}\right.$ and $\left.\mathrm{CH}_{4}\right)$ storage, and separation and capture of pollutant gases $\left(\mathrm{CO}_{2}, \mathrm{H}_{2} \mathrm{~S}, \mathrm{NO}_{\mathrm{x}}, \mathrm{SO}_{\mathrm{x}}, \mathrm{I}_{2}\right.$, etc. $){ }^{1,2} \mathrm{ZIFs}$ (zeolitic imidazolate frameworks) are a sub-family of MOFs with zeolite-like framework topology, formed from transition metals and imidazolate linkers, and well-known for their remarkable physical, chemical and thermal stability. ${ }^{3,4}$ Among those, a prototypical ZIF-8 $\left(\mathrm{Zn}[\mathrm{MeIM}]_{2}=\mathrm{ZnC}_{8} \mathrm{H}_{10} \mathrm{~N}_{4}\right.$; MeIM = methylimidazolate $)$ is one of the most studied. Its high BET specific surface area (SSA) $\left(\approx 2000 \mathrm{~m}^{2} \mathrm{~g}\right.$ ${ }^{1}$ ) and permanent porosity from its uniformly sized pore cavities (of $\approx 1.16 \mathrm{~nm}$ and pore volume of $\approx 0.60 \mathrm{~cm}^{3} \mathrm{~g}^{-1}$ ) are particularly desirable for many potential applications, such as molecular gas storage, ${ }^{3,5}$ separation by membrane sieving ${ }^{6}$ or kinetic diffusion, ${ }^{7}$ caging, ${ }^{8}$ templating, ${ }^{9}$ catalysis, ${ }^{8-10}$ and shape-selective distillation ${ }^{11}$ and sensing. ${ }^{12}$ A large quantity of ZIF- 8 can be readily synthesized by simple mixing of precursors of zinc nitrate/acetate and 2methylimidazole in a water or methanol solvent at room temperature. ${ }^{13}$ It is also commercially available from Sigma-Aldrich.

In addition to the synthesis of a variety of MOF structures, ${ }^{1-6}$ considerable effort has also been devoted to post-synthesis modifications of MOFs to obtain enhanced gas uptakes and selectivity. ${ }^{14}$ For example, the enhanced $\mathrm{CO}_{2}$ adsorption/selectivity in ZIF-8 is achieved by the application of a relatively high pressure $^{5 \mathrm{~b}}$ grafting basic groups via ammonia treatment, ${ }^{5 \mathrm{~d}}$ incorporation of amine groups in pores ${ }^{5 f, 5 \mathrm{~g}}$ or amine-linkers with partial ligand exchange, ${ }^{5 \mathrm{f}, 5 \mathrm{~h}}$ and/ or making hybrid structures. ${ }^{15}$ Very recently, the ZIF- 8 is also used to reactivate deceased diatoms, a diatomite composite composed of ca. $57.2 \mathrm{wt} \% \mathrm{ZIF}-8$ shows $\mathrm{CO}_{2}$ uptake of $0.80 \mathrm{mmol} \mathrm{g}^{-1}$ at $298 \mathrm{~K}, 1 \mathrm{bar}$, which is ca. $20 \%$ greater than that of pure ZIF-8. ${ }^{15 \mathrm{c}}$ Herein, for the first time, we show a new, simple but versatile approach to enhance the $\mathrm{CO}_{2}$ uptake and its binding energy with ZIF-8 by the creation of a locally defective structure using a well-controlled post-synthesis thermal annealing process close to its framework decomposition temperature. For example, a giant enhancement in $\mathrm{CO}_{2}$ uptake of over $100 \%$ at $25^{\circ} \mathrm{C}$ and 1 bar of $\mathrm{CO}_{2}$ is achieved in the modified ZIF-8 structures compared with the unmodified ZIF-8.

The ZIF-8 nanosized crystals were synthesized by a stirring precipitation method in a methanol solvent at room temperature (see experimental section in supporting information and Figure S1). As shown in Figure 1(a), the thermogravimetric analysis (TGA) of ZIF8 under inert atmosphere with a continuous temperature ramping rate of $5{ }^{\circ} \mathrm{C}$ per minute shows a framework decomposition / carbonization temperature of ca. $580{ }^{\circ} \mathrm{C}$, which is in good agreement with early reports. ${ }^{[3,16]}$ The continuous increase in temperature above $580{ }^{\circ} \mathrm{C}$ shows rapid decomposition and mass-loss by the evolution of a considerable amount of volatile $\mathrm{H}_{2}$, hydrocarbons and $\mathrm{C}-\mathrm{N}-\mathrm{H}$ species (Figure S2). During this process a disordered porous carbon network with $\mathrm{N}$-doping is observed but only at the expense of significant sample mass-loss of $(70-80) \%{ }^{13 g, 16}$ However, a controlled isothermal process between $400{ }^{\circ} \mathrm{C}$ and $550{ }^{\circ} \mathrm{C}$, i.e., at the verge of its framework decomposition / before carbonization, results in a modified framework structure of ZIF-8 with interesting properties and a minimal sample mass-loss of less than $15 \%$ (Figure 1). As represented by digital photographs in Figure 1 and S3, a carefully controlled post-synthesis thermal annealing under flowing argon between $400{ }^{\circ} \mathrm{C}$ and $550{ }^{\circ} \mathrm{C}$ results in a gradual transformation of white ZIF-8 into a brown material. The decomposition and carbonization of ZIF- 8 above $550{ }^{\circ} \mathrm{C}$ can be observed through its complete transition to black, presumably, carbon. 


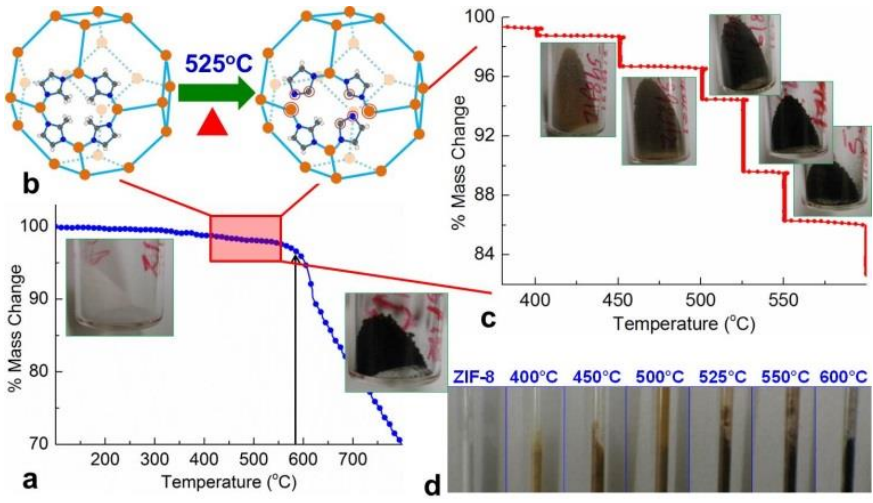

Figure 1. Steps in the optimization of the thermal annealing process of ZIF-8 and its conversion from white to brown material. a). TGA plot with continuous ramping rate of $5{ }^{\circ} \mathrm{C}$ per minute under argon flow showing a framework decomposition/carbonization temperature of ca. $580{ }^{\circ} \mathrm{C}$, indicated by vertical arrow. Highlighted rectangular region between $400{ }^{\circ} \mathrm{C}$ and $550{ }^{\circ} \mathrm{C}$ is selected for further isothermal annealing and structure optimization. b). Shows the sodalite (SOD) cage of ZIF-8 before and after thermal annealing at $525{ }^{\circ} \mathrm{C}$ for $3 \mathrm{~h}$. For clarity, the actual 2-methylimidazolate ligand is shown in one pore opening of the SOD cage, and rest is represented by wire frame with light blue. The colour: white- $\mathrm{H}$, blue- $\mathrm{N}$, grey-C and orange- $\mathrm{Zn}$ tetrahedra. c). Shows TGA plot of the controlled isothermal annealing at various temperatures. At each temperature the sample is annealing for $3 \mathrm{~h}$. d). Digital photographs of the thermal annealed powder samples in a $0.5 \mathrm{~mm}$ XRD glass capillaries. The annealing temperatures, each for $3 \mathrm{~h}$, are shown on top. The digital photographs of the actual as-obtained samples in its granular form in poly bottle are also shown in TGA plots at respective processed temperatures.

The controlled thermal annealing by combined thermogravimetry and mass-spectrometry (TG-MS) shows that the sample mass-loss is due to release of mainly the methyl groups (see the corresponding atomic mass unit (amu) signals at 12,13,14 and 15) on the framework ligands (Figure 2 and S4). A much more intense $\mathrm{CH}_{3}$ mass peak is observed between $500{ }^{\circ} \mathrm{C}$ and $550{ }^{\circ} \mathrm{C}$, specifically around $525{ }^{\circ} \mathrm{C}$ with further mass-loss compared to the other temperatures. Moreover if we assume that the TGA total mass-loss of the sample at these temperatures is entirely due to the decomposition of $\mathrm{CH}_{3}$, then the ca. $10 \%$ mass-loss at $525{ }^{\circ} \mathrm{C}$ accounts for $75 \%$ release of the methyl groups on the methylimidazolate ligands in a ZIF-8 unit cell formula unit, $\mathrm{Zn}[\mathrm{MeIM}]_{2}$. Release of both methyl groups in the formula unit accounts for a mass-loss of $13.2 \%$. Other, but relatively weak mass signals at 16,26 and 30 can be attributed to the recombination of fragmented free radicals in the gas phase. In contrary to the decomposition in Figure S2, no evident mass signal is detected for hydrogen and nitrogen. Furthermore, Figure 2c-d and S4 give a clear picture of differences between a controlled thermal annealing over a period of time and high temperature sample framework decomposition. If incubated for enough time the sample mass-loss at $500{ }^{\circ} \mathrm{C}$ is more or less equals to the sample left at $525^{\circ} \mathrm{C}$. The twostep TGA mass-loss behaviour with a mass-loss of ca. (6-7)\% and $13 \%$ roughly corresponds to the evolution of one and two equivalents of methyl groups. At or above $550{ }^{\circ} \mathrm{C}$ the more and rapid mass-loss is directly attributed to the actual sample decomposition.

As shown in Figure 3, the powder X-ray diffraction (PXRD) patterns of the annealed samples well support the TG-MS results. Most of these structures reveal the retention of cubic $I-43 m$ structure of ZIF-8 up to $525^{\circ} \mathrm{C}$. As evidenced by the sharp XRD peaks at low angles, the structures are still largely crystalline with long-range order, while the diminishment of XRD peak intensities at high angle suggests existence of local short-range disorder. More or less complete framework decomposition is observed at or above $550{ }^{\circ} \mathrm{C}$. Prolonged annealing of the samples at $500{ }^{\circ} \mathrm{C}$ and $525^{\circ} \mathrm{C}$ up to $24 \mathrm{~h}$ and $6 \mathrm{~h}$,
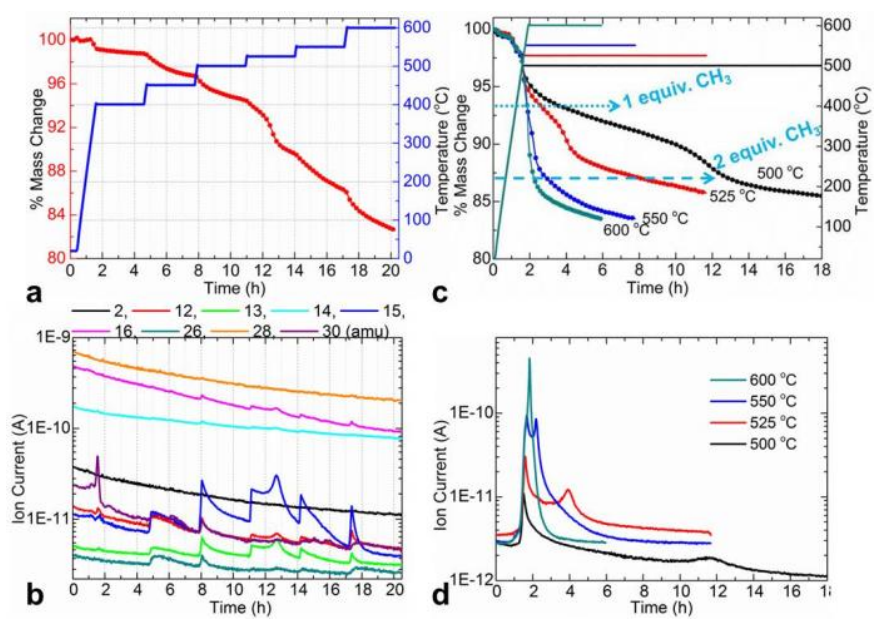

Figure 2. Combined TG-MS plots for controlled thermal annealing of ZIF-8. a). TGA mass-loss at different annealing temperatures. b). MS signals showing the evolution of various gaseous species represented by atomic mass unit (amu; $\mathrm{H}_{2}$ (2), $\mathrm{C}$ (12), $\mathrm{CH}$ (13), $\mathrm{CH}_{2}$ (14), $\mathrm{CH}_{3}$ (15), $\mathrm{CH}_{4}$ (16), $\mathrm{C}_{2} \mathrm{H}_{2}$ (26), $\mathrm{N}_{2}$ (28), $\mathrm{C}_{2} \mathrm{H}_{6}$ (30)) during the TGA process shown in (a). c). TGA mass-loss for prolonged isothermal annealing process at $500{ }^{\circ} \mathrm{C}, 525{ }^{\circ} \mathrm{C}, 550{ }^{\circ} \mathrm{C}$, and $600{ }^{\circ} \mathrm{C}$. d) $\mathrm{CH}_{3} \mathrm{MS}$ signal for TGA in (c). A clear distinct difference is seen for samples annealed at temperatures up to $525{ }^{\circ} \mathrm{C}$ and above. For the samples at $500{ }^{\circ} \mathrm{C}$ and $525{ }^{\circ} \mathrm{C}$ the two-distinct mass-loss steps are roughly equivalent to the evaporation of 1 and 2 equivalents of $\mathrm{CH}_{3}$ groups in a $\mathrm{ZIF}-8$ unit cell formula unit, the actual equivalent of mass-loss, $6.6 \%$ and $13 \%$, respectively, is represented by horizontal dashed arrows in light blue.
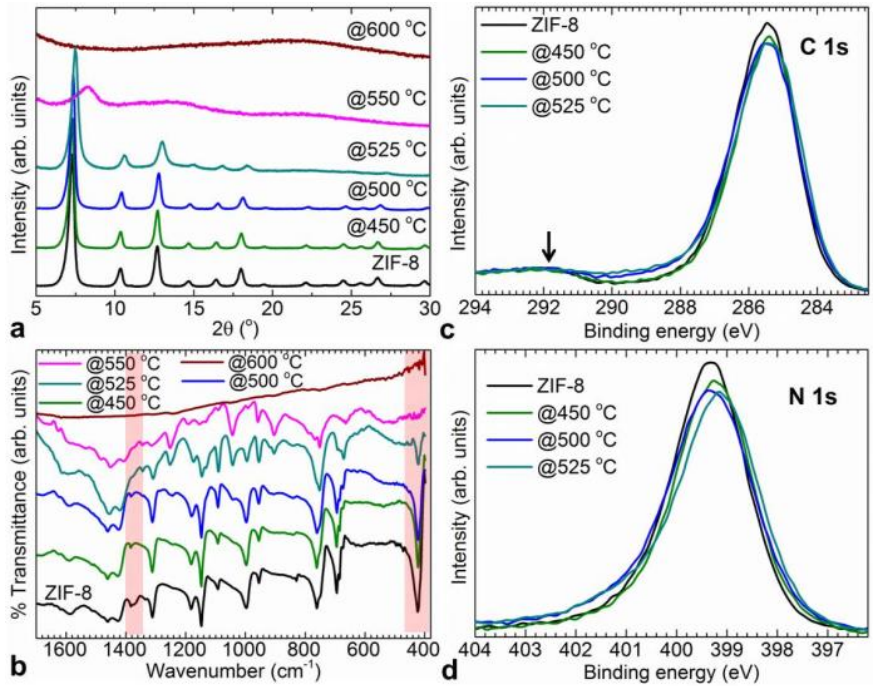

Figure 3. Structural characterizations of thermal annealed ZIF- 8 at various represented temperatures for $3 \mathrm{~h}$. a). PXRD patterns showing a similar and crystalline behaviour for samples up to $525{ }^{\circ} \mathrm{C}$, above which the diffused or amorphous nature indicates the sample decomposition. b). FTIR spectra showing existence of all framework IR absorption modes for samples up to $525^{\circ} \mathrm{C}$. c) \& d). XPS core level spectra of $\mathrm{C} 1 \mathrm{~s}$ and $\mathrm{N} 1 \mathrm{~s}$, respectively.

respectively, show a significant XRD peak broadening (Figure S5), which suggest a partly collapsed framework with disruption of longrange translational symmetry. A more promising evidence for retention of the ZIF- 8 framework structure in the annealed samples comes from the IR spectroscopic studies. As shown in Figure 3 and S6 the FTIR spectra of samples annealed up to $500{ }^{\circ} \mathrm{C}$ and $6 \mathrm{~h}$ are very similar to that of pure ZIF-8 except a considerably weakened $\delta$ $\mathrm{CH}_{3}$ IR mode at $1384 \mathrm{~cm}^{-1} .{ }^{5 \mathrm{c}}$ This implies that the main building block of the ZIF-8 structure is unchanged with the removal of the $\mathrm{CH}_{3}$ on the ligand. However prolonged or higher-temperature 
annealing (i.e., $24 \mathrm{~h}$ at $500{ }^{\circ} \mathrm{C}$ and $525^{\circ} \mathrm{C}, 550{ }^{\circ} \mathrm{C}$ ) results in a clear change in bonding/coordination among ligand $\mathrm{C}$ and $\mathrm{N}$, and $\mathrm{Zn}$ metal centres; particularly the strong IR mode at $422 \mathrm{~cm}^{-1}$ of the $\mathrm{Zn}-\mathrm{N}$ stretching is considerably weakened or completely disappears. $^{5 \mathrm{~b}}$ In addition there are several noticeable changes observed; softening/broadening of the $\mathrm{C}=\mathrm{N}$ stretch mode at $1584 \mathrm{~cm}^{-}$ 1 , weakening and shifting of the entire ring stretching convoluted bands at $1350-1500 \mathrm{~cm}^{-1}$, and in-plane and out-of-plane bending of the ring at $900-1350 \mathrm{~cm}^{-1}$ and $650-800 \mathrm{~cm}^{-1}$, respectively, all of which indicate disordering-induced weakening of the ring-ring ligand interactions within the ZIF- 8 framework structure. ${ }^{4 \mathrm{~b}}$ This is more pronounced in the $550{ }^{\circ} \mathrm{C}$ sample, where the extremely broadened IR spectrum indicates a very disordered structure, as also observed in PXRD patterns. At $525{ }^{\circ} \mathrm{C}$ and $550{ }^{\circ} \mathrm{C}$, the new IR modes at $904 \mathrm{~cm}^{-1}, 1041 \mathrm{~cm}^{-1}, 1251 \mathrm{~cm}^{-1}, 1886 \mathrm{~cm}^{-1}$ and $2200 \mathrm{~cm}^{-1}$ can be assigned to disordering-induced bonding environments between $\mathrm{C}$ and $\mathrm{N}$.

The local structural bonding environment in annealed ZIFs is further probed with X-ray Photoemission spectroscopy (XPS) (Figure 3 and S7). The core level $\mathrm{C} 1 \mathrm{~s}$ peak at binding energy (BE) of $285.4 \mathrm{eV}$ in ZIF-8 remains unchanged in most of the annealed samples, which is in good agreement with the $\mathrm{sp}^{2} \mathrm{C}=\mathrm{N}$ bonding. At high temperatures the complete decomposition $\left(600{ }^{\circ} \mathrm{C}\right)$ to carbonization $\left(800{ }^{\circ} \mathrm{C}\right)$ shows a gradual shift in the $\mathrm{C} 1 \mathrm{~s}$ peak position from $285.4 \mathrm{eV}$ to $284.6 \mathrm{eV}$, which indicates the transformation of $\mathrm{sp}^{2} \mathrm{C}=\mathrm{N}$ to a pure carbon. ${ }^{17}$ A shake-up satellite peak at $\approx 292 \mathrm{eV}$ in ZIF-8 is assigned to the delocalized $\pi$ conjugation $\left(\pi \rightarrow \pi^{*}\right)$ in the network. ${ }^{18}$ A gradual softening of this satellite peak at increased annealing temperature/time indicates the transition to localization is induced by disordering. ${ }^{18}$ An evident disordering-induced $\mathrm{C} 1 \mathrm{~s}$ peak broadening is also observed by a growing shoulder above the BE at $287 \mathrm{eV}$. A narrow symmetric peak at $399.4 \mathrm{eV}$ in $\mathrm{N}$ 1s XPS spectra of ZIF-8 indicates there is only one form of nitrogen in the framework. The peak shift to higher BE is observed for nitrogen when it is bound to metal (Me), which is estimated up to $\approx 1 \mathrm{eV}$ with respect to the position of $\mathrm{N}$ in a pyridinic environment $(398.8 \mathrm{eV})$ of imidazole structure. ${ }^{19}$ This is well supported by a peak shift to $398.8 \mathrm{eV}$ in a decomposed sample at $600{ }^{\circ} \mathrm{C}$. However, a peak shift of about 0.3 $\mathrm{eV}(399.4 \mathrm{eV}$ to $399.1 \mathrm{eV})$ in the annealed samples with a significant overlap with ZIF-8 is in good agreement with the reported BE shift for the transition of $\mathrm{Me}-\mathrm{N} 4$ to $\mathrm{Me}-\mathrm{N} 2$ (i.e., four N-coordination metal to two $\mathrm{N}) .{ }^{19}$ This gives further evidence to the weakened $\mathrm{Zn}-\mathrm{N}$ stretching IR mode in Figure 3b. Furthermore, a low intense shoulder at a higher $\mathrm{BE}$ above $400.5 \mathrm{eV}$ in the annealed samples at $\geq$ $500{ }^{\circ} \mathrm{C}$ is assigned to defect induced pyrrolic and quaternary nitrogen environments. ${ }^{20}$

All the above experimental data suggests the methyl dissociation and partial $\mathrm{Zn}-\mathrm{N}$ bond breaking in the annealed ZIFs have been achieved without the loss of the overall framework connection. We note that in a ZIF-8 crystal, the relatively weak chemical bonds are the $\mathrm{Zn}-\mathrm{N}$ coordination bond, and the $\mathrm{C}-\mathrm{C}$ bridging bond between the imidazolate ligand and the methyl group. Other bonds (on the imidazolate ligand) are all notably stronger. At elevated temperature, it is natural that the framework starts to break apart at the $\mathrm{Zn}-\mathrm{N}$ and $\mathrm{C}-\mathrm{C}$ connections. To understand why the methyl dissociation takes place first, we calculated the bond dissociation enthalpies of the $\mathrm{C}-\mathrm{C}$ bridging bond and the $\mathrm{Zn}-\mathrm{N}$ coordination bond using density functional theory (DFT). We obtained $321 \mathrm{~kJ} \mathrm{~mol}^{-1}$ and $353 \mathrm{~kJ} \mathrm{~mol}^{-1}$ for the two, respectively. (In comparison, the calculated bond dissociation enthalpies are $\approx 410 \mathrm{~kJ} \mathrm{~mol}^{-1}, \approx 602 \mathrm{~kJ} \mathrm{~mol}^{-1}, \approx 449 \mathrm{~kJ}$ $\mathrm{mol}^{-1}$ for the $\mathrm{C}-\mathrm{H}$, the $\mathrm{C}=\mathrm{C}$ and the $\mathrm{C}-\mathrm{N}$ bonds on the imidazolate ligand, respectively.) Also note that each $\mathrm{Zn}$ is coordinated with four
$\mathrm{N}$, and is sterically restricted within the framework, while the terminal $-\mathrm{CH}_{3}$ groups are sterically free. Consequently, upon heating, the $\mathrm{CH}_{3}$ group is able to break from the imidazolate ligand and enter the gas phase first. A complete breakage of the Zn-ligand connections would require higher temperature and/ or longer annealing.
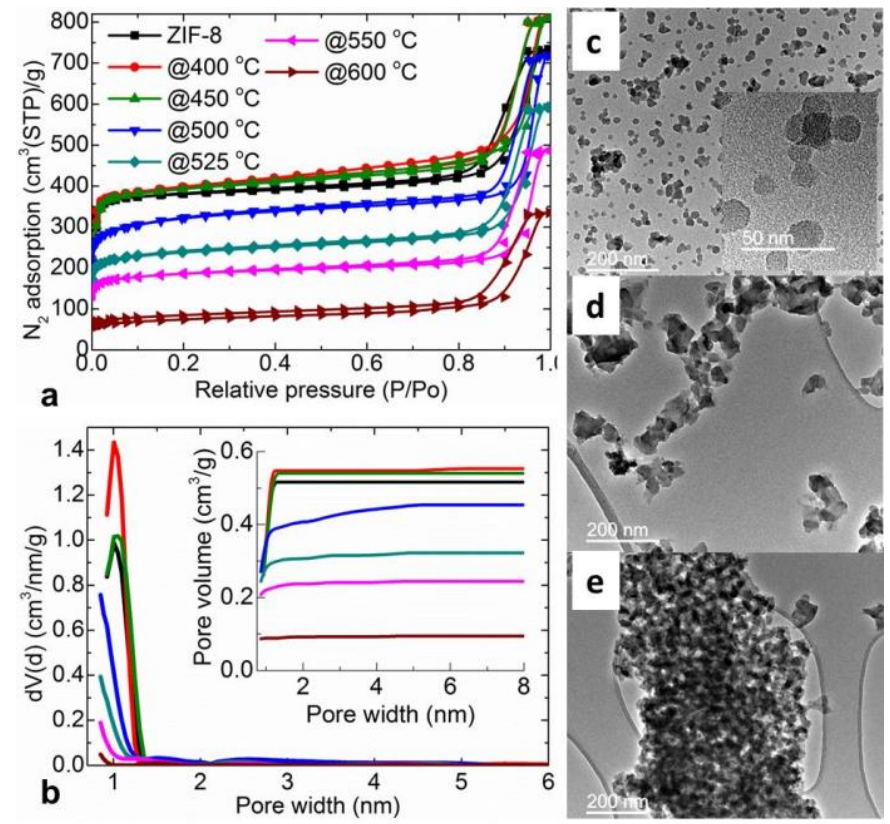

Figure 4. Surface and pore characteristics of the thermal annealed ZIF-8 samples up to $600{ }^{\circ} \mathrm{C}$, for $3 \mathrm{~h}$. a). $77 \mathrm{~K} \mathrm{~N}_{2}$ adsorption-desorption isotherms of thermal annealed samples showing a qualitatively similar isotherms. The second uptake at high relative pressures represents external capillary condensation effects in the gaps formed by nanosized particles. b). Pore size distribution plots and cumulative pore volume plots (inset) obtained by applying QSDFT model to $77 \mathrm{~K} \mathrm{~N}_{2}$ desorption isotherms in figure (a). c-e). TEM micrographs of initial ZIF-8, and $500{ }^{\circ} \mathrm{C}$ and $525^{\circ} \mathrm{C}$ annealed samples, respectively showing nanosized crystals. Inset of (c) shows average particle size of $25 \mathrm{~nm}$.

To understand further the annealed structures, their porosity characteristics were assessed through measurement of $\mathrm{N}_{2}$ isotherms at $77 \mathrm{~K}$. As shown in Figure 4 and $\mathrm{S} 8$, the $\mathrm{N}_{2}$ adsorption-desorption isotherms and corresponding pore volume plots estimate porosity retention of over $60 \%$ (both the BET SSA and micropore volume) in the annealed ZIFs obtained at temperatures up to $525{ }^{\circ} \mathrm{C}$. The isotherms and deduced quantitative data given in Table 1 clearly suggest the framework structure is mostly unchanged up to $450{ }^{\circ} \mathrm{C}$, which is again in good agreement with the FTIR and XPS data. The porosity starts to decrease in samples that are obtained at $\geq 500{ }^{\circ} \mathrm{C}$ and as expected the completely decomposed sample at $600{ }^{\circ} \mathrm{C}$ shows the lowest, which only accounts for $18 \%$ porosity retention relative to the starting ZIF-8. The reduced SSA and pore volume in the annealed samples can be attributed to some degree of locally disordered pore cavities. Thus apart from reduced SSA and pore volume the annealed structures also show a reduced cavity size below $1 \mathrm{~nm}$ (Figure 4 and S8). Here it is worth noting that the identical plateaus of $\mathrm{N}_{2}$ isotherms in the samples represent the existence of uniform pores, which is also revealed by pore size distribution and cumulative pore volume plots. The high $\mathrm{N}_{2}$ adsorption towards high relative pressures indicates the condensation effect in the externally formed macropores between nanoparticles. ${ }^{13 \mathrm{f}}$ In fact the TEM micrographs in Figure 4 show a particle size of ca. $25 \mathrm{~nm}$. 
Table 1. Sample preparation conditions; annealing temperature and time, SSA, micropore volume, $\mathrm{CO}_{2}$ uptakes at $298 \mathrm{~K}$ and IAST selectivity, $\mathrm{S}$ (see $\mathrm{SI})$ of $\mathrm{CO}_{2} / \mathrm{N}_{2}$.

\begin{tabular}{|c|c|c|c|c|c|}
\hline \multirow[t]{2}{*}{ Sample } & \multirow{2}{*}{$\begin{array}{l}\text { SSA } \\
\left(\mathrm{m}^{2} \mathrm{~g}^{-1}\right)\end{array}$} & \multirow{2}{*}{$\begin{array}{l}\mathrm{V}_{\text {micro }} \\
\left(\mathrm{cm}^{3} \mathrm{~g}^{-1}\right)\end{array}$} & \multicolumn{2}{|c|}{$\mathrm{CO}_{2}$ uptake $\left(\mathrm{mmol} \mathrm{g}^{-1}\right)$} & \multirow[t]{2}{*}{$\mathrm{S}_{\mathrm{CO} 2 / \mathrm{N} 2}$} \\
\hline & & & 0.15 bar & 1 bar & \\
\hline ZIF-8 & 1567 & 0.517 & 0.09 & 0.70 & 10 \\
\hline $3 \mathrm{~h} @ 400{ }^{\circ} \mathrm{C}$ & 1594 & 0.548 & 0.11 & 0.70 & 21 \\
\hline $3 \mathrm{~h} @ 450^{\circ} \mathrm{C}$ & 1549 & 0.541 & 0.14 & 0.82 & 19 \\
\hline $3 \mathrm{~h} @ 500{ }^{\circ} \mathrm{C}$ & 1217 & 0.407 & 0.19 & 0.98 & 34 \\
\hline $6 \mathrm{~h} @ 500{ }^{\circ} \mathrm{C}$ & 1200 & 0.405 & 0.22 & 1.08 & 30 \\
\hline $24 \mathrm{~h} @ 500{ }^{\circ} \mathrm{C}$ & 942 & 0.319 & 0.40 & 1.79 & 20 \\
\hline $3 \mathrm{~h} @ 525^{\circ} \mathrm{C}$ & 931 & 0.307 & 0.34 & 1.49 & 18 \\
\hline $6 \mathrm{~h} @ 525^{\circ} \mathrm{C}$ & 917 & 0.293 & 0.39 & 1.66 & 21 \\
\hline $3 \mathrm{~h} @ 550{ }^{\circ} \mathrm{C}$ & 711 & 0.237 & - & - & - \\
\hline $3 \mathrm{~h} @ 600^{\circ} \mathrm{C}$ & 316 & 0.092 & - & - & - \\
\hline
\end{tabular}
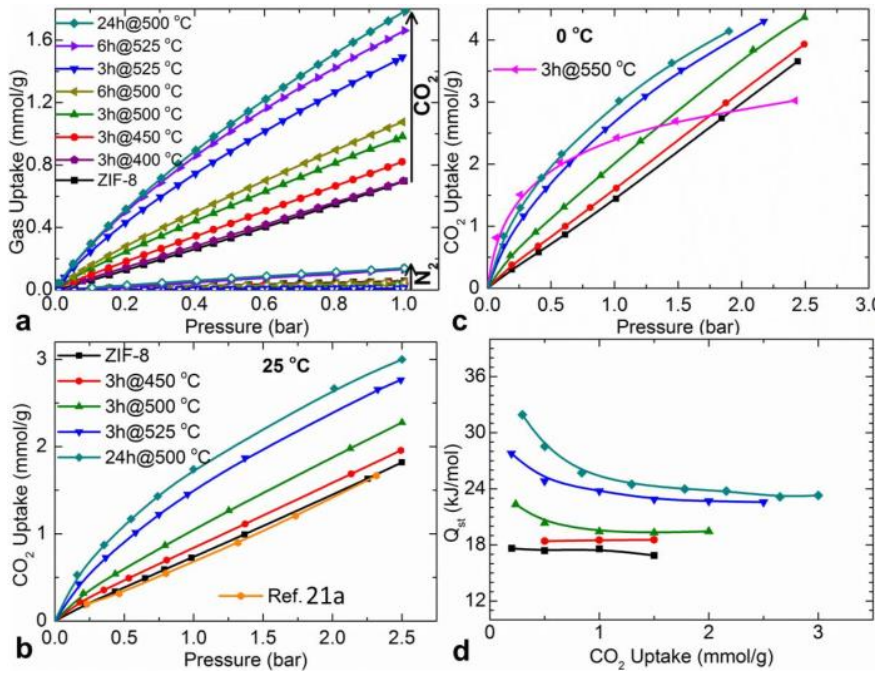

Figure 5. $\mathrm{CO}_{2}$ uptake characteristics of thermal annealed ZIF-8 samples. a). $25{ }^{\circ} \mathrm{C} \mathrm{CO}_{2}$ (solid) and $\mathrm{N}_{2}$ (open) uptake isotherms up to 1 bar in all the annealed samples. The labels represent the sample annealing temperature and period of annealing. b-c). $\mathrm{CO}_{2}$ uptake isotherms of samples up to $2.5 \mathrm{bar}$ at $25{ }^{\circ} \mathrm{C}$ and $0{ }^{\circ} \mathrm{C}$. (d) isosteric heat of adsorption against $\mathrm{CO}_{2}$ uptake. The same colour code and label is assigned to identify the sample in figures.

Finally the uptake isotherms of $\mathrm{CO}_{2}$ and $\mathrm{N}_{2}$ measured at $298 \mathrm{~K}$ are shown in Figure 5. Undoubtedly the annealed samples obtained at temperatures between $500{ }^{\circ} \mathrm{C}$ and $550{ }^{\circ} \mathrm{C}$ constantly show highly enhanced gas uptakes, more than twice that of ZIF-8 at 1 bar of $\mathrm{CO}_{2}$ (Figure 5a and Table 1). A similar trend is also observed when repeating the isotherm measurements at $0{ }^{\circ} \mathrm{C}$ (Figure $5 \mathrm{c}$ ) and $50{ }^{\circ} \mathrm{C}$ (Figure S9), respectively. In the annealed samples it is also worth noting the enhanced $\mathrm{CO}_{2}$ uptake above 1 bar of $\mathrm{CO}_{2}$. On the contrary, as shown in Figure 5c, a distinct effect of framework decomposition in the sample obtained at $550{ }^{\circ} \mathrm{C}$ is clearly observed by marked reduction in $\mathrm{CO}_{2}$ uptake. Most importantly, when considering the flue gas partial pressure region of 0.15 bar the annealed samples shows up to 4 times enhanced $\mathrm{CO}_{2}$ uptake compared to the ZIF-8 (Table 1). Thus as shown in Table 1 these optimized structures also show a highly enhanced $\mathrm{CO}_{2}$ selectivity over $\mathrm{N}_{2}$ (see SI for details), which is again 3 times higher to the initial ZIF-8. The enhanced $\mathrm{CO}_{2}$ uptake in the annealed structures is well supported by highly enhanced isosteric heat of adsorption $\left(\mathrm{Q}_{\mathrm{st}}\right)$ (Figure 5d), which is again nearly twice that of the original ZIF-8. The calculated $\mathrm{Q}_{\mathrm{st}}$ of $\approx 17 \mathrm{~kJ} \mathrm{~mol}^{-1}$ in ZIF-8 is in good agreement with the literature. ${ }^{5 e, 5 \mathrm{~h}, 21}$ It is noted that the original ZIF- 8 with its coordinatively saturated metal centres show a relatively very weak binding energy and low $\mathrm{CO}_{2}$ uptake capacity in the pressure range of interest. ${ }^{3,5 \mathrm{a}, \mathrm{d}-\mathrm{g}, 15 \mathrm{a}, \mathrm{c}, 21}$

Here we also note that the observed enhancement in $\mathrm{CO}_{2}$ uptake is higher than any of the previously reported post-synthesis treatments of ZIF-8. For example, a post-synthesis modified ZIF-8 using etheylenediamine and ammonia shows about 52\% and 25\% improved $\mathrm{CO}_{2}$ uptake at 1 bar of $\mathrm{CO}_{2}$ and $298 \mathrm{~K}^{5 \mathrm{~d}, \mathrm{~g}}$ On per SSA base, it is $10 \%$ and $32 \%$, respectively. The grand canonical Monte Carlo simulations study on amine functionalized structures, ZIF-8$\mathrm{NH}_{2}$ and ZIF-8-( $\left.\mathrm{NH}_{2}\right)_{2}$, only predict enhancement in $\mathrm{CO}_{2}$ uptake by $44 \%$ and $86 \%$, respectively. ${ }^{5 f}$ The others, $\mathrm{ZIF}-8 /$ diatomite composite and hybrid structure, $\mathrm{Zn}(\mathrm{mim})_{2} \cdot(\mathrm{Hmim})_{1 / 2} \cdot\left(\mathrm{H}_{2} \mathrm{O}\right)_{3 / 2}$ showed 0.8 $\mathrm{mmol} \mathrm{g}$ and $0.94 \mathrm{mmol} \mathrm{g}^{-1}$, respectively, compared with $0.7 \mathrm{mmol}$ $\mathrm{g}^{-1}$ in ZIF-8. ${ }^{15 \mathrm{a}, \mathrm{c}}$ As shown in Table 1 , the present annealed ZIF-8 samples consistently show significant enhancement in $\mathrm{CO}_{2}$ uptake, $\geq$ $1.5 \mathrm{mmol} \mathrm{g}^{-1}$, more than doubling the $0.7 \mathrm{mmol} \mathrm{g}{ }^{-1}$ capacity of ZIF8 ; or 4 times (or $300 \%$ ) higher than ZIF-8 on a per SSA basis. The $\mathrm{CO}_{2}$ uptakes in the annealed samples do not follow the usual trend with the SSA and/or pore volume, i.e., increased $\mathrm{CO}_{2}$ uptake with increasing porosity as observed in most porous solids dominated by physisorption. However, the enhanced $\mathrm{CO}_{2}$ uptake in the annealed samples with reduced porosity is consistent with the amine functionalized MOFs. ${ }^{5 f, g, 14}$ Furthermore, the $Q_{\text {st }}$ values for the annealed samples are also comparable to the MOFs with open-metal centres and / or amine functionalization. ${ }^{14,21}$ It has been widely investigated and accepted that the grafting of basic $\mathrm{N}$-containing functional groups on MOF pores always shows enhanced binding and uptake for $\mathrm{CO}_{2}$ due to the high affinity towards acidic $\mathrm{CO}_{2}$, mainly through the interaction of the lone-pair electrons on nitrogen. Thus the enhanced $\mathrm{CO}_{2}$ uptake and binding energy behaviour in the annealed samples can be directly correlated to the synergetic effects of locally defective structures with active carbon and nitrogen on the ligands, along with the exposed $\mathrm{Zn}$ sites (Figure 1b)., 2,5d-g,14,21

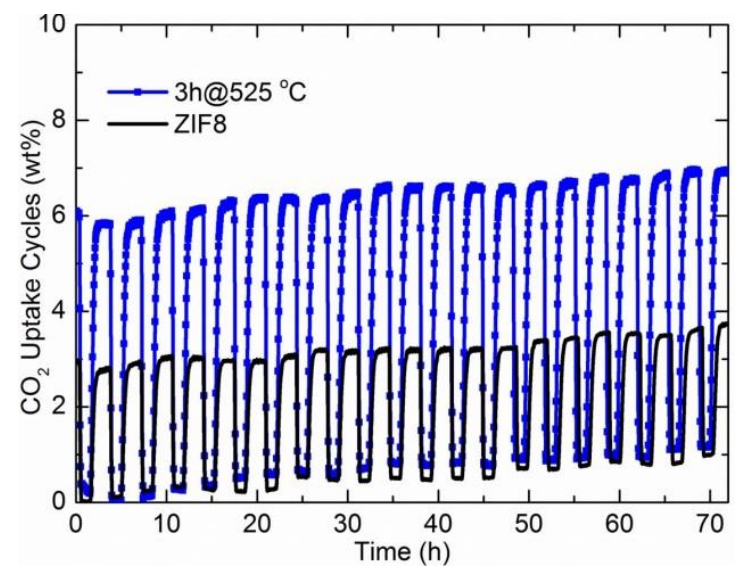

Figure 6. $\mathrm{CO}_{2}$ uptake cyclic stability up to 22 cycles on ZIF-8 and thermal annealed sample at $525^{\circ} \mathrm{C}$ for $3 \mathrm{~h}$.

In addition, we also carried out cyclic $\mathrm{CO}_{2}$ uptake tests in one of the annealed samples followed by PXRD and FTIR characterizations to show the structural stability. In a way, the repetitive uptake isotherms (Figure 5 and S9) following a uniform trend is a strong indication of high structural stability of the samples. Indeed, Figure 6 
shows cyclic $\mathrm{CO}_{2}$ uptake runs up to 22 cycles on both the ZIF-8 and the annealed sample. These tests were carried out on the TGA with repeating $\mathrm{CO}_{2}$ adsorption (at $25.5^{\circ} \mathrm{C}$ )-desorption (at $148{ }^{\circ} \mathrm{C}$ ) under flowing $\mathrm{CO}_{2}$ at 1 bar. Both samples maintain stable and similar cyclic performance and the uptake in the annealed sample more than doubles that of the ZIF-8 throughout all the cycles. The following PXRD and FTIR characterizations show excellent structural stability of the annealed sample (Figure S10). Therefore, the annealed samples can retain the robust framework structure with many enhanced active sites. Such structures may also benefit various other types of applications, such as catalysis, sensing and gas permeation membranes.

\section{Conclusions}

We have shown that a low-cost and facile method of tailoring the ZIF- 8 structure to enhance the $\mathrm{CO}_{2}$ uptake and $\mathrm{CO}_{2} / \mathrm{N}_{2}$ selectivity by a simple post-synthesis thermal annealing just below the framework decomposition temperature. The controlled thermal annealing selectively creates local defects but at the same time retains the overall framework structure. The local defects arise from partial dissociation of rotationally free methyl groups on the framework ligands and partly broken coordination between $\mathrm{Zn}-\mathrm{N} 4$. Thus the optimized structures are highly active and show marked enhancement in room temperature $\mathrm{CO}_{2}$ uptake of $\geq 1.5 \mathrm{mmol} \mathrm{g}^{-1}$ at 1 bar and $25{ }^{\circ} \mathrm{C}$ with a heat of adsorption of $\geq 30 \mathrm{~kJ} \mathrm{~mol}^{-1}$, which is over $100 \%$ greater than the $\approx 0.7 \mathrm{mmol} \mathrm{g}$ and $\approx 17 \mathrm{~kJ} \mathrm{~mol}^{-1}$, respectively for ZIF-8. These optimized structures also show very good structural stability with no apparent reduction on the sorption capacity after a number of uptake cycles. Thus our method demonstrates a new direction of tailoring MOF structures, which is relatively simple but very effective, compared with the other extensive post-synthesis chemical roots such as pore functionalization, ligand exchange, and metal decoration. More importantly, such a treatment may also be considered for enhancing MOF-based catalytic reactions and membrane gas permeations.

\section{Notes and references}

${ }^{a}$ Department of Chemistry, University College London, 20 Gordon Street, London, WC1H 0AJ, UK. E-mail: gsrinivasphys@gmail.com (S.G.); z.X.guo@ucl.ac.uk (Z.G.).

${ }^{b}$ NIST Center for Neutron Research, National Institute of Standards and Technology, Gaithersburg, Maryland 20899, USA.

$c$ Department of Materials Science and Engineering, University of Maryland, College Park, Maryland 20742, USA.

$\dagger$ This work is supported by the EPSRC grant no. (EP/G061785/1; EP/G063176/1).

Electronic Supplementary Information (ESI) available: [details of any supplementary information available should be included here]. See DOI: $10.1039 / \mathrm{c} 000000 \mathrm{x} /$

1. a) D. Britt, D. Tranchemontagne and O. M. Yaghi, Proc. Natl. Acad. Sci. U. S. A., 2008, 105, 11623; b) M. P. Suh, H. J. Park, T. K. Prasad and D.-W. Lim, Chem. Rev., 2012, 112, 782; c) Z. Zhang, Y. Zhao, Q. Gong, Z. Li and J. Li, Chem. Commun., 2013, 49, 653; d) H. Furukawa, K. E. Cordova, M. O'Keeffe and O. M. Yaghi, Science, 2013, 341, 974; e) J. A. Mason, M. Veenstra and J. R. Long, Chem. Sci., 2014, 5, 32.

2. a) T.-H. Bae, M. R. Hudson, J. A. Mason, W. L. Queen, J. J. Dutton, K. Sumida, K. J. Micklash, S. S. Kaye, C. M. Brown and J. R. Long,
Energy Environ. Sci., 2013, 6, 128; b) G. Srinivas, J. Burress and T. Yildirim, Energy Environ. Sci., 2012, 5, 6453; c) G. Srinivas, V. Krungleviciute, Z.-X. Guo and T. Yildirim, Energy Environ. Sci., 2014, 7, 335; d) C. Petit, B. Levasseur, B. Mendoza and T. J. Bandosz, Microp. Mesop. Mater., 2012, 154, 107; e) T. J. Bandosz, Cat. Today, 2012, 186, 20.

3. K. S. Park, Z. Ni, A. P. Cote, J. Y. Choi, R. Huang, F. J. UribeRomo, H. K. Chae, M. O'Keeffe and O. M. Yaghi, Proc. Natl. Acad. Sci. U. S. A., 2006, 103, 10186.

4. a) J. C. Tan, T. D. Bennett and A. K. Cheetham, Proc. Natl. Acad. Sci. U. S. A., 2010, 107, 9938; b) Y. Hu, H. Kazemian, S. Rohani, Y. Huang and Y. Song, Chem. Commun., 2011, 47, 12694; c) G. Ortiz, H. Nouali, C. Marichal, G. Chaplais and J. Patarin, Phys. Chem. Chem. Phys., 2013, 15, 4888.

5. a) H. Wu, W. Zhou and T. Yildirim, J. Am. Chem. Soc., 2007, 129, 5314; b) Y. Hu, Z. Liu, J. Xu, Y. Huang and Y. Song, J. Am. Chem. Soc., 2013, 135, 9287; c) G. Kumari, K. Jayaramulu, T. K. Maji and C. Narayana, J. Phys. Chem. A, 2013, 117, 11006; d) Z. Zhang, S. Xian, H. Xi, H. Wang and Z. Li, Chem. Eng. Sci., 2011, 66, 4878; e) C. Chen, J. Kim, D.-A. Yang and W.-S. Ahn, Chem. Engg. J., 2011, 168, 1134; f) D. Liu, Y. Wu, Q. Xia, Z. Li and H. Xi, Adsorption, 2013, 19, 25; g) Z. Zhang, S. Xian, Q. Xia, H. Wang, Z. Li and J. Li, AIChE J., 2013, 59, 2195; h) J. A. Thompson, N. A. Brunelli, R. P. Lively, J. R. Johnson, C. W. Jones and S. Nair, J. Phys. Chem. C, 2013, 117, 8198; i) D. F. Sava, M. A. Rodriguez, K. W. Chapman, P. J. Chupas, J. A. Greathouse, P. S. Crozier and T. M. Nenoff, J. Am. Chem. Soc., 2011, 133, 12398; j) J. T. Hughes, D. F. Sava, T. M. Nenoff and A. Navrotsky, J. Am. Chem. Soc., 2013, 135, 16256.

6. a) S. R. Venna and M. A. Carreon, J. Am. Chem. Soc., 2010, 132, 76; b) M. C. McCarthy, V. Varela-Guerrero, G. V. Barnett and H.-K. Jeong, Langmuir, 2010, 26, 14636; c) K. Díaz, L. Garrido, M. LópezGonzález, L. F. del Castillo and E. Riande, Macromolecules, 2010, 43, 316; d) L. Garrido, M. López-González, L. F. del Castillo and E. Riande, J. Membrane Sci., 2011, 383, 206; e) X. Zhong, Y. Jianhua, W. Jinqu, B. Ju, Y. Huimin, Y. Bing, L. Jinming, Z. Yan, Z. Liang and D. Chunying, Chem. Commun., 2012, 48, 5977; f) H. T. Kwona and H.-K. Jeong, Chem. Commun., 2013, 49, 3854.

7. a) C. Zhang, R. P. Lively, K. Zhang, J. R. Johnson, O. Karvan and W. J. Koros, J. Phys. Chem. Lett., 2012, 3, 2130; b) K. Zhang, R. P. Lively, C. Zhang, R. R. Chance, W. J. Koros, D. S. Sholl and S. Nair, J. Phys. Chem. Lett., 2013, 4, 3618.

8. a) D. Esken, S. Turner, O. I. Lebedev, G. V. Tendeloo and R. A. Fischer, Chem. Mater., 2010, 22, 6393; b) P.-Z. Li, K. Aranishi and Q. Xu, Chem. Commun., 2012, 48, 3173; c) A. Aijaz, A. Karkamkar, Y. J. Choi, N. Tsumori, E. Rönnebro, T. Autrey, H. Shioyama and Q. Xu, J. Am. Chem. Soc., 2012, 134, 13926; d) C.-H. Kuo, Y. Tang, L.Y. Chou, B. T. Sneed, C. N. Brodsky, Z. Zhao and C.-K. Tsung, $J$. Am. Chem. Soc., 2012, 134, 14345; e) H. R. Moon, D.-W. Lim and M. P. Suh, Chem. Soc. Rev., 2013, 42, 1807.

9. a) H.-L. Jiang, B. Liu, Y.-Q. Lan, K. Kuratani, T. Akita, H. Shioyama, F. Zong and Q. Xu, J. Am. Chem. Soc., 2011, 133, 11854; b) X. Zheng, Y. Li, Y. Xu, Z. Hong and M. Wei, CrystEngComm, 2012, 14, 2112; c) H. B. Wu, S. Wei, L. Zhang, R. Xu, H. H. Hng and X. W. Lou, Chem. Eur. J., 2013, 19, 10804.

10. a) C. Chizallet, S. Lazare, D. Bazer-Bachi, F. Bonnier, V. Lecocq, E. Soyer, A.-A. Quoineaud and N. Bats, J. Am. Chem. Soc., 2010, 132, 
12365; b) U. P. N. Tran, K. K. A. Le and N. T. S. Phan, ACS Catal., 2011, 1, 120; c) R.-Q. Zhong, R.-Q. Zou, T. Nakagawa, M. Janicke, T. A. Semelsberger, A. K. Burrell and R. E. D. Sesto, Inorg. Chem., 2012, 51, 2728; d) L. H. Wee, T. Lescouet, J. Ethiraj, F. Bonino, R. Vidruk, E. Garrier, D. Packet, S. Bordiga, D. Farrusseng, M. Herskowitz and J. A. Martens, ChemCatChem, 2013, 5, 3562.

11. a) S. A. Moggach, T. D. Bennett and A. K. Cheetham, Angew. Chem. Int. Ed., 2009, 48, 7087; b) J.-Q. Jiang, C.-X. Yang and X.-P. Yan, ACS Appl. Mater. Interfaces, 2013, 5, 9837; c) K. Zhang, R. P. Lively, C. Zhang, W. J. Koros and R. R. Chance, J. Phys. Chem. C, 2013, 117, 7214; d) J. A. Gee, J. Chung, S. Nair and D. S. Sholl, J. Phys. Chem. C, 2013, 117, 3169; e) Y. Wu, M. Zhou, B. Zhang, B. Wu, J. Li, J. Qiao, X. Guan and F. Li, Nanoscale, 2014, 6, 1105.

12. G. Lu and J. T. Hupp, J. Am. Chem. Soc., 2010, 132, 7832.

13. a) X.-C. Huang, Y.-Y. Lin, J.-P. Zhang and X.-M. Chen, Angew. Chem. Int. Ed., 2006, 45, 1557; Angew. Chem., 2006, 118, 1587; b) J. Cravillon, S. Münzer, S.-J. Lohmeier, A. Feldhoff, K. Huber and M. Wiebcke, Chem. Mater., 2009, 21, 1410; c) Y. Pan, Y. Liu, G. Zeng, L. Zhao and Z. Lai, Chem. Commun., 2011, 47, 2071; d) N. L. Torad, M. Hu, Y. Kamachi, K. Takai, M. Imura, M. Naito and Y. Yamauchi, Chem. Commun., 2013, 49, 2521; e) J. Yao, M. He, K. Wang, R. Chen, Z. Zhong and H. Wang, CrystEngComm, 2013, 15, 3601; f) K. Kida, M. Okita, K. Fujita, S. Tanaka and Y. Miyake, CrystEngComm, 2013, 15, 1794; g) A. J. Amali, J.-K. Sun and Q. Xu, Chem. Commun., 2014, 50, 1519.

14. a) K. K. Tanabe and S. M. Cohen, Chem. Soc. Rev., 2011, 40, 498; b) M. L. Foo, R. Matsuda and S. Kitagawa, Chem. Mater., 2014, 26, 310 .

15. a) R. Chen, J. Yao, Q. Gu, S. Smeets, C. Baerlocher, H. Gu, D. Zhu, W. Morris, O. M. Yaghi and H. Wang, Chem. Commun., 2013, 49, 9500; b) R. Kumar, K. Jayaramulu, T. K. Maji and C. N. R. Rao, Chem. Commun., 2013, 49, 4947; c) D. Liu, J. Gu, Q. Liu, Y. Tan, Z. Li, W. Zhang, Y. Su, W. Li, A. Cui, C. Gu and D. Zhang, Adv. Mater., 2014, 26, 1229.

16. a) W. Chaikittisilp, M. Hu, H. Wang, H.-S. Huang, T. Fujita, K. C.W. Wu, L.-C. Chen, Y. Yamauchi and K. Ariga, Chem. Commun., 2012, 48, 7259; b) Q. Wang, W. Xia, W. Guo, L. An, D. Xia and R. Zou, Chem. Asian J., 2013, 8, 1879.

17. A. P. Dementjev, A. de Graaf, M. C. M. van de Sanden, K. I. Maslakov, A. V. Naumkin and A. A. Serov, Diamond Relat. Mater., 2000, 9, 1904

18. a) A. Ganguly, S. Sharma, P. Papakonstantinou and J. Hamilton, J. Phys. Chem. C, 2011, 115, 17009; b) C. Hontoria-Lucas, A. J. LópezPeinado, J. de D. López-González, M. L. Rojas-Cervantes and R. M. Martín-Aranda, Carbon, 1995, 33, 1585; c) J. Diaz, G. Paolicelli, S. Ferrer and F. Comin, Phys. Rev. B, 1996, 54, 8064.

19. K. Artyushkova, B. Kiefer, B. Halevi, A. Knop-Gericke, R. Schloglc and P. Atanassov, Chem. Commun., 2013, 49, 2539.

20. W. Ding, Z. Wei, S. Chen, X. Qi, T. Yang, J. Hu, D. Wang, L.-J. Wan, S. F. Alvi and L. Li, Angew. Chem. Int. Ed., 2013, 52, 11755.

21. J. M. Simmons, H. Wu, W. Zhou and T. Yildirim, Energy Environ. Sci., 2011, 4, 2177; b) H. Wu, W. Zhou and T. Yildirim, J. Am. Chem. Soc., 2009, 131, 4995. 